\title{
Characterization of durian (Durio zibethinus) monthok from Blora, Central Java, Indonesia
}

\author{
Arif Susila ${ }^{1}$, Yayuk Aneka Bety ${ }^{1}$, Yulis Hindarwati $^{1}$, Forita Dyah Arianti ${ }^{1}$, Dyah Haskarini ${ }^{1}$, \\ Afrizal Malik ${ }^{2}$, Budi Santoso ${ }^{3}$, and Intan Gilang Cempaka ${ }^{1 *}$ \\ ${ }^{1}$ Assessment Institute for Agricultural Technology (AIAT) of Central Java, Indonesia \\ ${ }^{2}$ Assessment Institute for Agricultural Technology (AIAT) of East Java, Indonesia \\ ${ }^{3}$ BKSDA of Central Java, Indonesiaa
}

\begin{abstract}
The study was conducted from April 2019 to Maret 2020 in a community forest in the village of Karang Kembang, Tunjungan district, Blora. The objective of the research was to characterize the morphology of Durian Monthok from Blora. The research directly developed the morphological characters of such durian from Blora. Description format durian plants have been arranged in the form of standard blanks. The results showed that Durian Monthok had a greyed-orange flower (163C), moderate yellow (161A) skin, weight rate of $1,877-2,172 \mathrm{~kg}$. It was also determined that Durian Monthok had an oblong fruit shape, light greenishyellow (8C) flesh, fluffier sweet taste, and had a fragrant aroma.
\end{abstract}

\section{Introduction}

Durian (Durio zibethinus Murr.) is one of the tropical fruits native to Indonesia, which has very diverse types and has different physical characters compared to durian in general [1]. Most durian fruits are not cultivated but collected from the forest. Durian is usually cultivated in the yard, not only in Indonesia but also in other countries. Other Asia, except in Thailand and Malaysia in where large durian plantations are commonly found. Durian is varied in taste, aroma, flesh color, the shape of the fruit, and the presence of the seeds [2]. The fruit characters are most commonly used as a marker of the durian cultivar. Based on morphological characteristics of the fruits, durian cultivars could be determined precisely after the plant reach a minimum of 8 years of age [3], especially for plants that are propagated through seeds.

To obtain the actual plant phenotype, the characterization of plants, fruit, and flowers can complement leaf characterization. Durian fruit character is often a distinguishing feature. Local people usually give the name of durian according to the character of the fruits. In addition to fruits' character, characterization of leaves, stems, and flowers can be described to determine the distinguished character. Plant breeding for high-yielding durian varieties can be helped by durian morphological characterization [4]. The diversity of a variety can be described by morphological characters, [5].

* Corresponding author: intangilangcempaka@gmail.com 
Furthermore, the objective of the research was to characterize the morphology of Durian Monthok from Blora. Durian Monthok has been registered as local variety at the Ministry of Agriculture. This registration aims to increase the economic value of Durian Monthok, and can be continued with the variety release.

\section{Materials and methods}

The study was conducted in April 2019-Maret 2020 in Karang Kembang, Tunjungan, Blora. One parent tree cultivar of Durian Monthok was used in this research. Fresh leaves and fruits were examined by taking 10 samples. Observations were made on various durian fruit characters. Description format durian plants have been arranged in the form of standard blanks [6] . Observed characters include external appearance tree (height, growth, tree trunk, canopy, trunk texture, color), leaves (shape, edge, tip, leaf color, type, width, length, petiole size, number of leaves/stalks, distance between leaves), flower (color, stem color, flower stand, diameter, number flower/bunch, petal color, flowering duration, number of stamens, number of pistils, crown color, stamen color, pistil color, flower stalk length, stalk panicle link shape, and flower tip shape), fruit (shape, length, width, depth of wedge, fruit tip shape, skin color, flesh color, moisture texture, aroma), part of the thorn (length, density, type). Another character who observed in the fruit are seeds (length, width, thickness, number of seed/fruits, shape, and color), and fruit quality characters (fruit weight, edible portion flesh color). Plant identification was carried out to determine Genus, Species, local name, Indonesian name, Latin name.

Durian Monthok has been planted since 1989 and can be observed because as parent tree minimum five seasons production. According to Yuniastuti et al, [7] in durian plants, the stability of the plant can be seen from its production capacity for 5 seasons, if the production is stable, it can be used as a parent tree. The Royal Horticulture Society's color chart was used to determine color. Cameras were used for plant documentation. The data were analyzed by descriptive by noting related things with morphological characters and fruit quality which is displayed in the form of a table and picture.

\section{Results and discussions}

Durian Monthok was collected from Blora District. The durian accession has been registered in PPVTPP. It grows in the Perhutani area. The farmer who planted Durian Monthok planted from seed. One mother tree was examined for morphometric analysis. The identification of durian diversity can be done through morphology [8] 
Table 1. Taxonomy and character of Durian Monthok from Blora.

\begin{tabular}{|l|l|}
\hline Group determination & Description \\
\hline Taxonomy & \\
\hline Domain & Eukaryota \\
\hline Kingdom & Plantae \\
\hline Phylum & Spermatophyta \\
\hline Subphylum & Angiospermae \\
\hline Class & Dicotylodene \\
\hline Order & Malvales \\
\hline Family & Bombacaceae \\
\hline Genus & Durio \\
\hline Species & Durio zibethinus \\
\hline Characters & \\
\hline Tree height & $25 \mathrm{~m}$ \\
\hline Tree growth & Spreading \\
\hline Circumference tree trunk & $143 \mathrm{~cm}$ \\
\hline Canopy shape & Symmetrical \\
\hline Canopy width & $10-15 \mathrm{~m}$ \\
\hline Tree trunk shape & Round \\
\hline Tree branch & Curved upward \\
\hline Location of the lowest branch & $>5 \mathrm{~m}$ \\
\hline Trunk texture & Coarse \\
\hline Trunk color & Greyed orange (164 A) \\
\hline Tree canopy & Shady \\
\hline & \\
\hline
\end{tabular}

Trees on durian Monthok were identified as having symmetrical spreading character. The shape of the canopy of the durian Monthok is a pyramidal crown and has horizontal branches. The plant grows horizontally and forms a variety of angles. There is a lot of branches forming a canopy similar to a cone or triangle [9]. It has a canopy width of $10-$ $15 \mathrm{~m}$ with a curved upward tree branch, and the trunk texture is coarse with greyed-orange (164 A) color. Table 1 illustrates that the taxonomy and character of the Durian Monthok in Blora were similar to Durio zibethinus [10]. Durian Monthok grows at an altitude of 400 meters sea level. The rainfall range is around $1500-2500$ millimeters per year. Air temperature $27^{\circ} \mathrm{C}-32^{\circ} \mathrm{C}$, humidity $75-80 \%$. The environment for Durian Monthok is suitable according to Widyawati [11]. The suitable soil conditions for planting durian are loose soil, contains a lot of organic, slightly sandy, durian cannot stand waterlogging which can cause root rot disease. Suitable soil pH is between $5.5-6.5$. The tree height is between 25-50 meters depending on the variety, has a lush canopy, the color of the bark is blackish brown [10]. 
Table 2. Leaves and flowers character of Durian Monthok from Blora.

\begin{tabular}{|l|l|}
\hline Group determination & Description \\
\hline Leaves & \\
\hline Shape & Elypse \\
\hline Edge & Flat \\
\hline Tip & Acute \\
\hline Bottom color & Green (137A) \\
\hline Upper color & Grey-brown (199A) \\
\hline Type & Lanceolate \\
\hline Direction & Semi-erect \\
\hline Width & $4.5-5.5 \mathrm{~cm}$ \\
\hline Length & $12-16 \mathrm{~cm}$ \\
\hline Petiole size & $1.5-2 \mathrm{~cm}$ \\
\hline Number of leaves/stalks & $6-8$ \\
\hline Distance between leaves & $1-2 \mathrm{~cm}$ \\
\hline Petiole color & Green (NN 137A) \\
\hline Flowers & \\
\hline Flower color & Greyed-orange (163C) \\
\hline Stem color & Greyed-brown $(199 \mathrm{~A})$ \\
\hline Flower stand & On stem \\
\hline Flower diameter & $25-30 \mathrm{~cm}$ \\
\hline Flower/bunch & $1.6-1.8 \mathrm{~cm}$ \\
\hline Petal color & Greyed-orange (163C) \\
\hline Flowering duration & 1 week \\
\hline Number of stamens & $54-57$ \\
\hline Number of pistils & 1 \\
\hline Crown color & Greyed-orange (163C) \\
\hline Stamen color & Greyed-orange (163C) \\
\hline Pistil color & Greyed-orange (163C) \\
\hline Flower stalk length & $2.0-2.7 \mathrm{~cm}$ \\
\hline Stalk panicle link shape & Type III \\
\hline Flower tip shape & Rounded \\
\hline
\end{tabular}

Table 2 showed that the leaf from Durian Monthok was elliptic. The petiole and leaf blade are part of the durian leaf. Durian Monthok leaf shape is ellipse, with flat edge and acute tip. Durian leaf shape are varied, such as elliptical, obovate and oval [12]. Durian has flat edge and smooth, with thin flat leaves, which is which is the optimal form for photosynthesis gas exchange [13]. The leaf tip acute with the bottom color is green (137A) and the upper leaf color is grey-brown (199A). Durian Monthok has a lanceolate leaf type, with a semi-erect direction, and has $4.5-5.5 \mathrm{~cm}$ width and $12-16 \mathrm{~cm}$ length and a green (NN 137A) petiole color. It has a glossy top surface and a matte bottom surface. Inside the leaf, there are two types of leaf chlorophyll, namely blue-green chlorophyll and greenyellow chlorophyll. Plant species, light, and magnesium content affect the amount of chlorophyll $[13,14]$. 


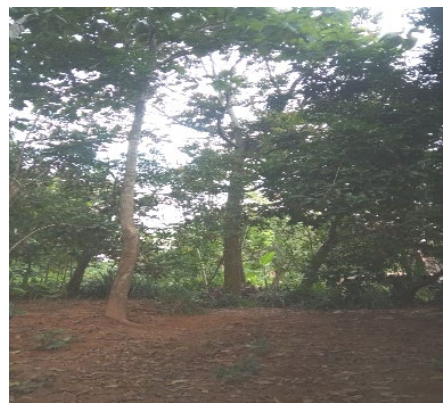

(a)

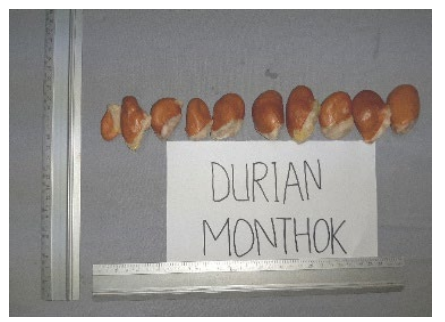

(d)

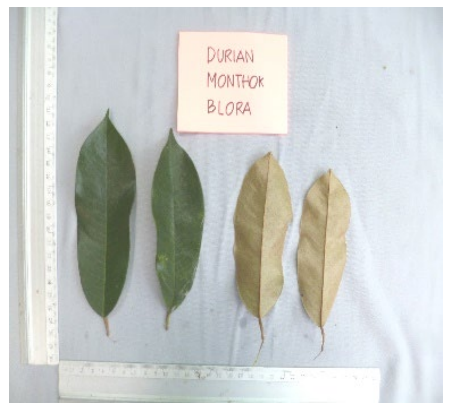

(b)

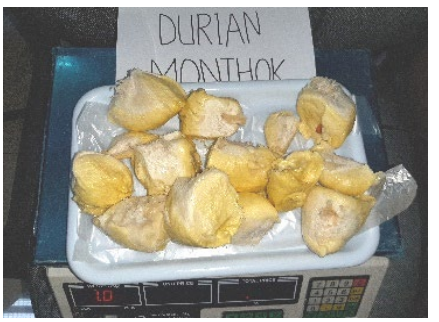

(e)

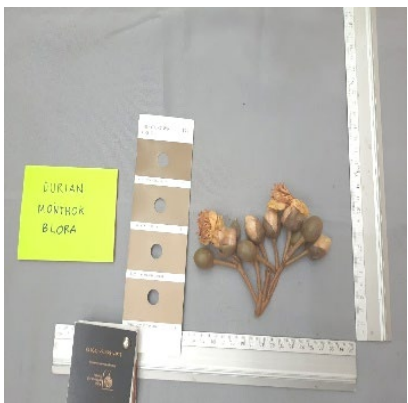

(c)

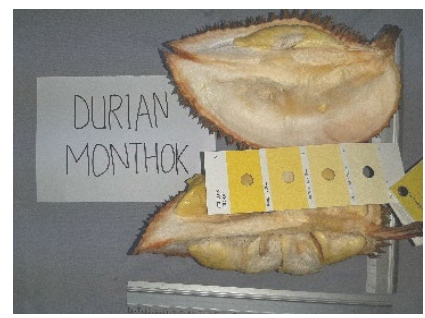

(f)

Fig. 1. Picture of the Durian Monthok: (a) tree; (b) leaves; (c) flower, (d) seed, (e) flesh, and (e) fruit.

Flowers and fruits are generative organs of durian (Figure 1). Characterization of the generative parts of plants can be carried out due to the right season. Durian Monthok flower appears in December 2019. Flower clusters in durian appear from November to December on primary or secondary scaffold branches [15]. Cluster hanging from a branch with the flowers are hanging down. The climatic conditions in Blora have significant rainfall between monsoons and rainfall throughout the season between $1496 \mathrm{~mm}$ to $2506 \mathrm{~mm}$. According to Oldeman, Blora district includes zones C3 and D3 which are characterized by dry months of 4-6 months and wet months of 4-5 months. The average monthly air temperature ranges from $26.5^{\circ} \mathrm{C}$ to $28.4^{\circ} \mathrm{C}$ and the annual average is $27.5^{\circ} \mathrm{C}$ [16]. This condition is a suitable climate for durian. Climate factor such as the rainy season throughout the year makes durian able to produce fruit [17]. Durian Monthok has greyedorange (163C) flower color, with greyed-brown (199A) stem color with flower stands all over the stem. It has a $25-30 \mathrm{~cm}$ flower diameter, with $1.6-1.8$ flower/bunch with greyed-orange (163C) petal color. Durian Monthok flower duration was 1 week with 54 57 number of stamens and 1 pistil and has the same color of crown, stamen, and pistil which is greyed-orange (163C). 
Table 3. Fruits of Durian Monthok from Blora.

\begin{tabular}{|l|l|}
\hline Group determination & Description \\
\hline Fruits & \\
\hline Fresh Weight & $1.877-2.172 \mathrm{~kg}$ \\
\hline Shape & Obovoid \\
\hline Length & $20-24 \mathrm{~cm}$ \\
\hline Width & $15-20 \mathrm{~cm}$ \\
\hline Depth of wedge & $2.0-2.1 \mathrm{~cm}$ \\
\hline Fruit tip shape & Pointed \\
\hline Fruit base shape & Flat \\
\hline Fruit skin color & Grey-yellow $(161 \mathrm{~A})$ \\
\hline Presence of thorn & Presence \\
\hline Thorn length & $0.9-2.0 \mathrm{~cm}$ \\
\hline Thorn density & Moderate \\
\hline Thorn type & Convex tapered \\
\hline Skin thickness & $0.5-0.8 \mathrm{~cm}$ \\
\hline Edible portion & $0.670-0.726 \mathrm{~kg}$ \\
\hline Flesh color & Yellow $(8 \mathrm{C})$ \\
\hline Thickness & $0.5-1.0 \mathrm{~cm}$ \\
\hline Taste & Sweet \\
\hline Flesh texture & Fine \\
\hline Moisture content & Slightly wet \\
\hline Aroma & Stimulate \\
\hline Seed length & $3.5-5.5 \mathrm{~cm}$ \\
\hline Seed width & $2.4-3.5 \mathrm{~cm}$ \\
\hline Seed thickness & $0.6-2.0 \mathrm{~cm}$ \\
\hline Number of seed/fruits & $11-12$ \\
\hline Seed shape & Long round \\
\hline Seed color & Greyed-orange $(\mathrm{N} 167 \mathrm{~A})$ \\
\hline & \\
\hline & \\
\hline
\end{tabular}

Durian Monthok has $1.877-2.172 \mathrm{~kg}$ fresh weight and an obovoid shape. The percentage of edible portion is $33-35 \%(0.670-0.726 \mathrm{~kg})$. Score the percentage of this fruit flesh is medium until heavy same as percentage of edible portion North Aceh's superior durian ranges from 24.3 to $46.7 \%$ with a mean of $30.5 \%$ [18]. Durian fruit has proportions heavy fruit flesh when the value is $30 \%$ total weight of fruit [6]. Meanwhile, according to durian observers and the durian festival criteria are $28-30 \%$. It has $20-24 \mathrm{~cm}$ length and $15-20 \mathrm{~cm}$ width. Pointed fruit tip and flat fruit base. It has grey-yellow (161 A) and a presence thorn (Table 3). The color of durian fruit is green and when ripe it turns into green, dark green, or dull green. Durian fruit is a tropical plant, so it can grow well in Indonesia [10]. The length of a ripe durian fruit can reach $30-45 \mathrm{~cm}$ with a width of $20-25$ $\mathrm{cm}$, and a weight between 1.5-2.5 kg. Each fruit contains 5 pieces in which lies 1-5 seeds covered with colored fruit flesh white, cream, yellow, or dark yellow. Each durian variety determines the size of small fruit size, taste, texture, and thickness of the flesh [12].

The color of the flesh on the durian generally has its charm in the durian consumption rate [2]. Local durians are favored by domestic consumers because of their sweet taste, medium to the strong aroma, attractive yellow color, thick flesh, and high fruit productivity [20]. Meanwhile, foreign consumers prefer durian which is unscented, sweet taste, slightly bitter, thick flesh, and yellowish flesh color. Accession of local durian Monthok is very popular because it has thick flesh with flesh color yellow and creamy white, has a sweet taste with a soft and dry fruit texture, the presence of medium fruit fiber and small fruit seeds. These characters are different from the results of the characterization of Kawuk Durian fruit from Blora Regency as follows weight $1.326 \mathrm{~kg}$ (light), elliptical shape, 
general skin color is green group $143 \mathrm{~B}$, type of convex spines, skin thickness, $9.25 \mathrm{~mm}$ (thin), the weight of the flesh is $0.21 \mathrm{~kg}$ (light), white group color (NN155 A), medium texture, medium juice content, and has strong sweet with a weak bitter taste and strong aroma [21]. The fruit is strong sweet with a weak bitter taste and strong aroma. Durian Monthok can be continued for a certification test for seed production because durian Monthok has a morphological character that suits people's preferences, such as sweet taste, medium to strong aroma, obovoid fruit shape and yellow flesh color. These characters can be heritant that can be passed down to the offspring. Morphological characters being passed on to the next generation. This may be due to environmental factors affecting the expression this character [22].

\section{Conclusion}

This research concludes that Durian Monthok grows in Blora Regency have unique and distinctive as durian local variety, such as sweet taste, medium to the strong aroma, obovoid fruit shape, and yellow flesh color. It has been registered as a local variety to increase the economic value.

\section{References}

1. M. Belgis, C. H. Wijaya, A. Apriyantono, B. Kusbiantoro, N. D. Yuliana, Int. Food Res. J., 23, 4, (2016)

2. S. Susilawati, M. Sabran, Bul. Plasma Nutfah, 24, 2, 92018)

3. A. Retnoningsih, E. S. Rahayu, I. P. Sari, J. Sains dan Teknol., 14, 2, (2016)

4. N. S. Nasri Baroroh, Fitmawati, et al., JOM FMIPA, 1, 2, (2014).

5. Bioversity, Descriptors for durian (Durio zibethinus Murr.). (Bioversity International, Rome, Italy, 2007)

6. Direktorat Perbenihan Direktorat Jenderal Hortikultura, Pedoman Teknis Penyusunan Deskripsi Varietas Hortikultura, vol. 53, no. 9. 2013.

7. E. Yuniastuti, A. Anggita, Nandariyah, Sukaya, Local durian (Durio zibethinus murr.) exploration for potentially superior tree as parents in Ngrambe District, Ngawi, IOP Conf. Ser. Earth Environ. Sci., 142, 1, (2018)

8. S. Lestari, Fitmawati, N. N. Wahibah, Bul. Kebun Raya, 14, 2, (2011)

9. A. D. Sawitri, E. Yuniastuti, Nandariyah, Morphological characterization of local durian as parent tree in Bitingan District, Rembang, IOP Conf. Ser. Earth Environ. Sci., 250, 1, (2019)

10. M. J. Brown, Int. Plant Genet. Resour. Inst., 1997, https://books.google.com/books?hl=en\&lr=\&id=3AcGwT0CdSwC\&oi=fnd\&pg=PR3 $\& \mathrm{dq}=$ macrophya,,$+\% 22$ u.k. $\% 22+$ (forage,$+\mathrm{OR}+$ foraging,$+\mathrm{OR}+$ visit,$+\mathrm{OR}+$ visitng,$+\mathrm{OR}$ + pollinate)\&ots=UyZhodFnOy\&sig=6EdcWozxAWjRXSDBjCY_86ccxNk.

11. A. T. Widyawati, Mini Review: Teknologi inovasi budidaya durian di Kalimantan Timur, 3, (2017)

12. E. Yuniastuti, N. Nandariyah, S. R. Bukka, Caraka Tani J. Sustain. Agric., 33, 2, (2018)

13. D. W. M. P. Solomon, L. R. Berg, Biology 8th Edition. (2008)

14. Mł. Ewa, Acta Biol. Cracoviensia Ser. Bot., 51, 1, (2009)

15. C. Honsho, K. Yonemori, A. Sugiura, S. Somsri, S. Subhadrabandhu, J. Am. Soc. Hortic. Sci., 129, 1, (2004) 
16. E. Karuniawati, Mulyono, G. Supangat, Evaluasi Kesesuaian Lahan untuk Tanaman Durian (Durio zibethinus Murr.) di Desa Tunjungan Kecamatan Tunjungan Kabupaten Blora Jawa Tengah, http://repository.umy.ac.id/handle/123456789/29201

17. L. N. Effendi, IDENTIFIKASI MORFOLOGI DURIAN (Durio zibethinus) SUNAN DAN BRONGKOL DALAM PENYUSUNAN BASIS DATA KERAGAMAN. 2013.

18. R. S. Handayani, I. Anas, J. Hortik. Indonesia, 8, 3, (2017)

19. R. S. K. N. Muh, A. H. Swasono, Agromix, 8, 2, (2017)

20. E. D. Mustikarini, N. S. Khodijah, Y. Yulistia, AGROSAINSTEK J. Ilmu dan Teknol. Pertan., 1, 1, (2017)

21. D. Nugraheni, D. Haskarini, H. Yulis, Karakteristik Buah Durian Kawuk ( Durio Zibethinus Rumph . Ex Murray) Dari Desa Tunjungan, Pros. Semin. Nas. Kesiapan Sumber Daya Pertan. dan Inov. Spesifik Lokasi Memasuki Era Ind. 4.0 (2019)

22. H. Suskendriyati, A. Wijayati, N. Hidayah, D. Cahyuningdari, Biodiversitas J. Biol. Divers., 1, 2, (1970) 